\title{
Initiating a Meaningful Assessment of Early Childhood Development during the Covid-19 Pandemic
}

\author{
Luluk Rochanah \\ Lulukrochanah31@gmail.com \\ STITNU Al Hikmah Mojokerto
}

\begin{abstract}
Assessment of early childhood development during the pandemic Covid-19 really needs to be done in order to monitor the process and progress of children's learning optimally and continuously through a systematic, periodic and continuous process to collect data, conduct analysis, document and make decisions and make reports on developments. child. This study uses a qualitative approach based on a phenomenological perspective, with interview, observation, and documentation techniques. This study aims to determine the growth and development of Religious and Moral Values, Physical Motoric, Cognitive, Language, Social Emotional and Art, obtain initial information related to obstacles or disorders in child growth and development, how to stimulate services with children's developmental needs, provide appropriate support appropriate for children, how to stimulate services with children's development needs, provide appropriate support to children from parents when learning from home.
\end{abstract}

Keywords: Assessment, early childhood development, Pandemi Covid-19

(C) 2021 Luluk Rochanah

This work is licensed under a Creative Commons Attribution-ShareAlike

\section{INTRODUCTION}

Assessment in early childhood is a measurement of the stages of child development achieved by children from the results of children's learning activities. Assessment of Early Childhood Education learning uses a real (authentic) approach which is an assessment of learning processes and outcomes to measure the level of attainment of attitudinal (spiritual and social) knowledge and skills based on actual facts and reality. Assessments carried out in early childhood are carried out in a systematic and sustainable comprehensive manner that includes the growth and development that has been achieved by the child.

Assessment of child development is also a systematic, periodic and continuous process to collect data, perform analysis, document and make decisions and make reports on child development. Early Childhood Assessment is a process of 
collecting and processing information to measure the achievement of children's learning activities. Assessment of the results of learning activities by educators is carried out in order to monitor the process and progress of children's learning optimally and continuously. Based on this assessment, educators and parents of children will obtain information about developmental achievements related to attitudes, knowledge, and skills possessed by children after carrying out learning activities. In the context of standard-based education, competency-based curriculum, and continuous learning approach, assessment of learning processes and outcomes provides an overview of the level of achievement of children's development, manifested in the competence of children's attitudes, knowledge, and skills.

The implementation and assessment mechanism refers to PAUD standards, namely Permendikbud 137 of 2014 article 18 and Permendikbud 146 of 2014 which states that the assessment standard is a criterion regarding the assessment of children's learning processes and outcomes in order to meet the standards for the level of achievement of children's development according to their age level.

Mulyasa (2012: 198) states, "Early childhood education assessment is important to know how much impact education programs have on behavior and attitudes, both in the short, medium and long term". Efforts to improve the quality of education can be pursued through improving the quality of learning and the quality of the assessment system. Both are interrelated, a good learning system will produce good quality learning. The quality of this learning can be seen from the results of the assessment (Harun et al, 2009:12). NAEYC National Association for The Education of Young Children states that assessment is a process of observing and documenting the work done by students and recording the ways in which students do it, to serve as the basis for various educational decisions that affect children.

What is very important in the learning process is the assessment and reporting of early childhood development carried out by the teacher, with the assessment and reporting the teacher can find out whether the child has been able to achieve development in accordance with the achievements that the child must have. In fact, the assessment and reporting of progress is carried out by the teacher from the time the child arrives at school until the child returns home. The teacher assesses 6 aspects of child development including the Development of Religious Moral Values, Physical, motor, language, cognitive, social, emotional and art by making observations on spiritual, social, knowledge and skills attitudes ranging from behavior, speech, facial expressions, and activities. while at school by using a variety of assessment techniques ranging from observation, work, performance, checklists and others.

During the Covid-19 pandemic, all early childhood children who attend school take lessons from home (online). If children usually receive guidance and care from teachers in the classroom, at this time it is parents who have to guide and care for children, especially early childhood. Teachers do not just stand still. Teachers also continue to assess children's development through parents. But how to do that assessment? The assessment itself is a process of measuring the results of children's learning activities and must be based on real activities. The measurement is based on the results of behavioral observations, work, performance made by children.

However, during the COVID-19 pandemic, learning must be done from home so that teachers have difficulty observing and assessing children's development. Teachers have difficulty how to assess children's development in accordance with the 
competence and characteristics of children, this is due to the lack of cooperation between parents in providing optimal stimulation related to children's development at home and reporting on children's activities while at home. Therefore, very urgent knowledge is needed regarding how to assess and report child development when learning is carried out at home.

During the Covid-19 Pandemic, it is hoped that parents will assist teachers in observing the growth and development of children. Parents observe various activities and activities of children at home through observing all activities carried out by children, such as where children get information, inspiration and insight. Parents observe from what children say, including facial expressions, movements, and children's work, whether in the yard, in the living room, in the kitchen, bathroom, or in bed. In this learning activity, parents at home only observe and record children's learning activities in the form of videos or take photos of the children's work and then convey it to the teacher through online media.

In addition to these activities, parents also need to observe the child's physical growth, including measuring body weight, height/body length, and head circumference. But if parents have difficulties related to internet signal or unstable network, parents can tell the activities carried out by telephone directly to the teacher or via WA. It is necessary to carry out this assessment, so that teachers and parents know the development of children's learning in accordance with the achievements of children's development, observe what things children know, what children can do, and what are the habits of children when learning from home.

Related to the results of these observations, the teacher designs learning programs according to the interests, strengths, and needs of children. In this case, parents experience limited knowledge regarding assessment, so schools must provide parents with online assessment capabilities.

\section{METHODOLOGY}

This type of research uses a phenomenological qualitative research type to develop understanding by using a case study strategy. In this case, the researcher seeks to synergize with KB, TK, RA institutions in Sidoarjo to establish cooperation and create networks with other institutions with an interest in understanding the competence of teachers and parents related to assessing children's development when learning from home.

The reason for choosing a child development assessment during learning from home during the covid pandemic is to observe and understand the extent of parental stimulation for child development in order to achieve optimal child development. The specification of this research is field research, the main source of data is teacher research data at early childhood education institutions ranging from $K B, T K, R A$ in Sidoarjo Regency. The informants of this research were the principal, guardian of students, teachers, students, education observers and related agencies. The assessment research technique uses a sampling technique because the sample is taken unexpectedly from the population based on certain characteristics or traits. Based on the reasons for selecting the subject with a total of 25 institutions and characteristics because the researcher considers these criteria to be able to represent the characteristics of subjects who can provide information by digging up information from parents, teachers or people closest to the subject that will be used to 
obtain data validity, the results of which will support supporting data. which can reveal the importance of assessing children's development when studying from home during the covid -19 pandemic.

Data Analysis Techniques The data collection in this study was using several research instruments, namely observation, interview guidelines and document analysis.

1. Observation Methods Observations made by utilizing information technology became the spearhead of observation activities carried out such as the use of cellphones and handy cameras and the work sent by parents.

2. Methods Interviews are conducted by interacting and communicating directly with the informants to be interviewed. Interviews were conducted directly with key informants such as school principals, parents and guardians of students, teachers, closest people, the head of HIMPAUDI, the head of IGRA and related agencies.

3. Documentation Documentation Method is to find valid data through the documentation of Assessment Results in the form of annual programs, semester programs, weekly programs and daily programs, checklist assessments, work assessments, observation assessments, performance assessments as complementary data for primary data obtained through observations and interviews. In the process of analyzing data that is truly believed to be true, the researcher checks research members/subjects from method data sources, by using an extension of the observation time on the assessment of children's development while studying from home during this covid pandemic.

\section{RESULTS AND DISCUSSION}

Initiating a meaningful assessment of children's development during the covid pandemic in Sidoarjo is as follows:

In principle, the implementation of learning from home is carried out in accordance with the principles contained in the letter of the minister of education and culture no 4 of 2020 regarding the implementation of policies during the spread of coronavirus disease Covid-19 ie

1. The safety of the physical and mental health of students, educators, unit heads and all members of the education unit is the main consideration and implementation of learning.

2. Learning from home BDR activities are carried out to provide a learning experience without burdening the demands of complete curriculum achievement.

3. BDR learning from home can be focused on life skills education.

4. Inclusive learning materials are age-appropriate with the age and level of character education and the specific type of learners.

5. Activities and assignments during BDR (learning from home) may vary between regions, educational units according to their respective interests and conditions, including considering BDR facilities (learning from home).

6. Student learning outcomes during BDR are given qualitative feedback. Based on the above policy, educators have made guidelines and changes to learning activities from home so that children's development is optimally stimulated. 
Teacher preparation in assessing early childhood development in participating in learning from home is not the same as school days when studying at school, what teachers need to prepare is 1) planning / determining activities, 2) preparing assessment tools, 3) collecting data and processing, 4) report the results of the assessment. Assessment preparation begins when we prepare the RPPM (Daily Learning Program Plan). In preparing the RPPM the teacher determines the learning activities and objectives of learning and determines what aspects and indicators will be made to assess the child. The indicators here are measures, characteristics, or characteristics of basic abilities that can be achieved by children. The teacher must clearly understand the program implementation activities that will be carried out in order to optimally improve what abilities the child has. The second step that must be done is to prepare an assessment tool as a guide for teachers in conducting assessments. Many assessment tools can be used to obtain child assessment data, but not all assessment tools are appropriate to reveal all aspects of early childhood growth and development.

1. Planning for PAUD learning activities during the Covid Pandemic

Through the making of RPPM and RPPH it may not be done every day in order to make it easier for parents to optimally stimulate child development learning from home according to the child development plan that has been set by the teacher. The time for carrying out the assessment. Parents can make observations on various activities of children's activities at home anytime and anywhere from the time the child wakes up until he goes back to sleep at night. Both in the yard, in the living room, in the kitchen, in the bathroom, and in bed. If parents have sent via WA, or reported by telling children's activities, the teacher begins to assess various information related to aspects of physical growth and 6 aspects of development, namely religious and moral values, physical motor development (gross and fine motor movements, and physical health), cognitive development, language, socialemotional, and artistic.

2. How to prepare assessment tools, teachers prepare assessment tools Assessment

Tools, are used to produce information as evidence of progress on early childhood development and learning learning from home by any procedure, formal or informal. Formally, for example in the form of interviews, measurement equipment (for physical). While informally, for example in the form of observations, portfolios, narratives, anecdotal notes.

To document the results of children's assessments, teachers can ask parents to send photos of their children's work or videos of the learning process from home. Delivery of assessment results via email or WA. The teacher continues by assessing the work through WA and videos of the child's learning process from home related to 6 aspects of child development according to the RPPM sent to parents, including:

NAM (Moral Religious Values): how children can say a prayer to sleep, a prayer to want eat, read Surah Al Fatihah, Surah Al-Iklash.

Physical gross motor: Playing a bicycle in front of the house, helping to clean up toys

Fine motoric: Folding paper into animals, ringing animal necklaces

Cognitive : : Counting the number of animals in the house

Bahasa : Retell the activities of caring for animals that have been

kids do withParents 
Art

Social Emotions
: Painting the animals in the house

: Cleaning toys, helping parents wash the utensils animals in the house

3. Collecting data and processing the

Results of children's work reported by parents according to aspects that have been sent by the teacher can be in the form of habituation attitudes to reading prayers, helping parents, tidying toys, handwork, artwork or skills, such as: drawing animals, folding paper to form animals painting collage results from cutouts / scribbles from the results of building blocks made by children from playdough or sand. To make it easier for the teacher to make an assessment, the teacher can ask parents to write down the name and date the work was made by the child, and don't forget to write everything down. said by the child to confirm the work he made so as not to be wrong when the teacher made an interpretation of the work. Next, the teacher will process the assessment by analyzing what has been sent by the student's guardian in the form of the child's work with the achievement of basic competencies that are appropriate for the child's development. These results It is important for teachers to obtain data on the growth and development of children as a whole when learning from home.

\section{Reporting the results of assessment}

Assessment that has been carried out will be useful if it is reported to parents without reporting the assessment will only be understood by the assessor with the reporting it will be used by many teachers, parents and foundations that will be used as a basis for decisions, reporting the results of the assessment is the responsibility of the teacher who refers to the main principle of reporting which must describe the progress of children's development from 6 aspects of child development (religious morals, physical motoric, cognitive, language, art) that have been achieved by children when participating in learning from home during the covid-19 pandemic

The report submitted by the teacher to the parents is in the form of a brief description of the child's development, which includes six aspects of development, namely the development of religious behavior and morals, cognitive development, language development, physical/motor development, artistic development and social emotional development. Reporting on child development aims to help teachers plan further learning in accordance with child development during the COVID-19 pandemic, provide information to parents about children's progress and support the smooth running of teacher and parent programs.

Assessments carried out during the COVID-19 pandemic must be authentic which can describe authentic assessments of child development, because they are centered on children's development to participate in learning activities on how to learn about the subject. Authentic assessment when learning from home must describe what attitudes, skills, and knowledge the child has or has not had, how the child applies the acquisition of knowledge. In this case the teacher must be able to identify what activities can be continued and for what assessment activities must be carried out. Therefore, authentic assessment must be part of learning activities from home. Basically, authentic assessment has the same main character as the process of teaching and learning activities. Authentic assessment is expected to be able to develop children's development optimally. 
This authentic assessment is carried out when children are involved in play activities, and daily habituation activities are carried out in natural conditions. As planned by the teacher, children learn to recognize the ability of geometric shapes, so parents must be able to prepare to look for objects around the home environment related to geometric shapes such as children being invited to play making cakes in the form of circles, squares, triangles, etc., children are invited to observe the shape of the cupboard, balls, roofs, wheels etc. This assessment is a reflection of the interaction between the individual and his environment, and with the child's growing abilities (proficiency) not a reflection (reflection) of his innate abilities. The assessor must pay attention to the process that produces the product, namely the process of interaction between the child and his environment and is conducive and the changes that occur due to the increase in new abilities in his development (proficiency) the focus of the assessment is directed at this.

In the assessment activities, the identification of learning assessments during the covid pandemic period contains elements of creativity, criticalness, communication, and collaboration (creativity, critical thinking, communication, collaboration). The most appropriate assessment for early childhood is carried out by observing the growth and development of children from time to time, so that the progress of children's development can be seen in accordance with the events that occur which are experienced by children by observing what children see, what they see. children's activities can be done, and what are the attitudes and habits of children when carrying out learning from home. And various information about children's progress are learning outcomes that need to be conveyed via WA, email, interviews with teachers.

The procedure for assessing the growth and development of early childhood during the COVID-19 pandemic includes:

1. What was observed? To get data on the growth and development of children, parents can observe:

a. Words spoken by the child (question, statement, refutation, Entertaining.

b. The behavior shown by the child (helping mother, tidying toys, using twigs to make scratches, inviting friends to talk, etc.).

c. Facial expressions (angry, sad, disappointed, happy, frowning, etc.).

d. Child's body language (kicking, stomping, hugging, patting the shoulder etc.).

e. Children's work (scribbles, cutting results, collages, roncean, paintings, drawings, using natural materials, metal, wood and bamboo, thread and cloth, glass and ceramics, plastic and straws, and loose parts) ).

2. when do the observations? observations were made ranging from children waking up the child will sleep. At the time of going to assess in advance the old oran see how RPPM that have been sent to parents to child development observed nothing out of the standard ICP (of indicators development) that has been determined by the teacher

3. How to make observations? Observations are done by seeing what the children are doing, paying attention, and listening to the chatter of the children. At the time of observing the teacher must always be ready with recording equipment such as writing instruments, cellphones, and camera To document children's activities and identify the ICP of the child to be assessed. 
During the Covid pandemic, this assessment of learning from home is very beneficial for children, including maintaining children's growth so that they are healthy and maintained, children's development becomes more optimal, children receive support according to their needs with their growth and development needs, For teachers, so that teachers can know growth children, knowing the development of Religious and Moral Values, Physical Motoric, Cognitive, Language, Social Emotional and Art, getting initial information related to obstacles or disorders in children's growth and development, knowing how to stimulate services with children's developmental needs, providing appropriate support to children, teachers have data and information about children's growth and development as a guide for making lesson plans.

For parents, getting information about children's growth, development and interests, makes it easier for parents to provide appropriate and sustainable stimuli at home, make decisions with parents and PAUD services in providing support in meeting children's needs.

The implementation of the assessment culminates in reporting the child's development which will be submitted to parents in the form of a brief description of the child's development, which includes six aspects of development, namely the development of religious behavior and morals, cognitive development, language development, physical/motor development, artistic development and social development. emotional.

Reports to related parties on child development are prepared through a process of synthesis, interpretation, and communication analysis in which reporting on child development aims to help teachers plan further learning in accordance with child development, provide information to parents about children's progress and support the smooth running of teacher and parent programs. old. The implementation of reporting this activity should maintain the confidentiality of data or information, that data or information about students is only informed and discussed with the parents of the students concerned or experts in the context of further guidance.

\section{CONCLUSION}

Conclusion of the study initiated a meaningful assessment of early childhood development during the covid-19 pandemic where an assessment of child development must be carried out by teachers to obtain results on how far the child's development is during the COVID-19 pandemic through several assessment techniques in accordance with early childhood assessment standards and through reporting techniques sent by parents, when learning from home, learn with parents how parents can optimally provide stimulation in accompanying children to learn from home based on the guidelines that have been planned by the teacher which cannot be separated from the basic competencies of early childhood.

\section{ACKNOWLEDGEMENT}

Thanks also to the Journal of Childhood Development which has received and published our research. Also thanks to principals, guardians of students, teachers, students, education observers and the Sidorejo Regency Office who have been willing to provide assistance as research data. 


\section{REFERENCES}

Agustin, M,. \& Wahyudin, U. 2011. Penilaian Perkembangan Anak Usia Dini.

Bandung: Refika Aditama.

Arikunto, Suharsimi. 2008. Dasar-dasar Evaluasi Pendidikan. Jakarta: Bumi Aksara.

Arief, Armai. 2002. Pengantar Ilmu dan Metodologi Pendidikan Islam. Jakarta: Ciputat Pers.

ASpinelli, A, and G. Pellino. 2020. "COVID-19 Pandemic: Perspectives on an Unfolding Crisis." British Journal of Surgery 107 (7): 785-87. https://doi.org/10.1002/bjs.11627.

http:/ / abusyakir80.blogspot.com/2015/03/evaluasi-pendidikan-anak-usiadini.html/25 januari 2019.19:58

https://edukasi.kompas.com/read/2020/06/26/083044471/begini-cara-melakukanpenilaian-perkembangan-anak-paud-selamapandemi?page=all.Penulis,AlbertusAdit diunduh 21 Maret 2021

Jo Basford \& Caroline Bath, 2014, Playing the assessment game: an English early childhood education perspective, Early Years An International Research Journal, Pages 119-132 | Received 09 Nov 2013, Accepted 07 Mar 2014, Published online: 24 Apr 2014, Volume 34, https:/ / doi.org/10.1080/09575146.2014.903386

Kementrian Pendidikan dan kebudayaan direktorat pembinaan pendidikan anak usia

dini. (2015). Penilaian Pembelajaran Pendidikan Anak usia dini.

Kemendikbud. 2015. Peraturan Menteri Pendidikan Dan Kebudayaan Republik Indonesia Nomor 146 Tahun 2014 Tentang Kurikulum 2013 Pendidikan Anak Usia Dini. Jakarta: Menteri Pendidikan Dan Kebudayaan Republik Indonesia

Mulyasa. 2012. Manajemen PAUD. Bandung: PT. Remaja Rosdakarya

Moleong, Lexy J. 2006. Metodologi Penelitaian Kualitatif. Bandung: PT. Remaja Rosda Karya

Mahyuddin, Nenny. 2008. Penilaiant Anak Usia Dini. Padang : UNP Press Wortham

Sue. Assessment in Early Childhood Education, Ohio: Pearson Merrill Prentice Hall, New Jersey, Columbus, 2005

Wulandari, Hesti, and Edi Purwanta. 2020. "Pencapaian Perkembangan Anak Usia Dini Di Taman Kanak-Kanak Selama Pembelajaran Daring Di Masa Pandemi Covid-19." Jurnal Obsesi : Jurnal Pendidikan Anak Usia Dini 5 (1): 452. https://doi.org/10.31004/obsesi.v5i1.626.

International Journal of Early Years Education ISSN: (Print) (Online) Journal homepage: https://www.tandfonline.com/loi/ciey20 Informal early childhood education: the influences of parents and home on young children's learning Jane Murray To cite this article: Jane Murray (2021) Informal early childhood education: the influences of parents and home on young children's learning, International Journal of Early Years Education, 29:2, 117-123, DOI: 10.1080/09669760.2021.1928966 To link to this article: https://doi.org/10.1080/09669760.2021.1928966 
In a Time of COVID-19 and Beyond, the World needs Early Childhood Educators Jane Murray To cite this article: Jane Murray (2020) In a Time of COVID-19 and Beyond, the World needs Early Childhood Educators, International Journal of Early Years Education, 28:4, 299-302, DOI: $10.1080 / 09669760.2020 .1839830$ To link to this article: https://doi.org/10.1080/09669760.2020.1839830 